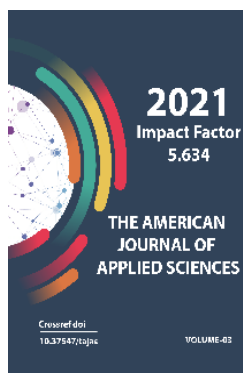

\title{
Problems Of Informatization Of Management Of Agricultural Industry And Modeling Of Agriconomic System In A Market Economy
}

Farrukh Do'stmirzayevich Juraev

Researcher Karshi Engineering-Economical Institute, Uzbekistan

Journal Website: http:|

theamericanjournals.c

om/index,php/tajabe

Copyright: Original content from this work may be used under the terms of the creative commons attributes 4.0 licence.

\section{ABSTRACT}

The article describes the importance and relevance of macroeconomic modeling in the development of economic sectors. The problems of applying the methods of macroeconomic modeling (both optimization and simulation) in the practice of planning and managing the national economy are analyzed.

\section{KEYWORDS}

Economy, macroeconomic modeling, forecast, optimization, imitation, national economy, regulation of the economy

\section{INTRODUCTION}

In the agrarian policy of the state, the main target provisions that are substantiated in the book of the President of the Republic of Uzbekistan Sh.M.Mirziyoyev "In the State Program for the Implementation of the Strategy of Action in Five Priority Areas of Development of the Republic of Uzbekistan in
2017-2021, directly determines the specific tasks facing the sociology of public opinion", the development of agriculture and related industries of industrial processing is defined as a priority in a market economy. In accordance with this agrarian sector, the economy is undergoing an intensive process of forming a market system and mechanisms for its 
functioning. New types of enterprises are being created locally, entrepreneurship and farming are developing, a multi-structured agrarian economy and a new management system corresponding to it are formed. For this, the necessary legal base and social atmosphere have been created in the republic, active control over the level of employment of the population and stabilization of the economy is being conducted, thereby protecting market competition.

In such conditions, one of the priority areas of scientific support for the development of the agrarian sector of the economy is information support for the goods of manufacturers and governing bodies of the agro-industrial complex (AIC).

For this, multi-level information communication technologies and databases must be created on the basis of modern computers, which at the right time provided the farmer, tenant or manager with the information necessary to make informed decisions on production, income and expenses. The creation of systems is also a complex and multifaceted process associated with the development of its model algorithmic and methodological foundations. In Uzbekistan, the development of models and algorithmization of agro-economic systems has been carried out since the early 60s. In this scientific direction, located at the junction of biological and economic cybernetics, having obtained a number of fundamental results that are important theoretical and practical value for modeling agriculture and creating systems for informatization of management in the agroindustrial complex. Results can be grouped in three directions:

First - this is a macroeconomic modeling of the development of agriculture and agroindustrial complex;
Second - farming systems modeling;

Third - development of models and methods of crop management and technological processes of primary processing of cotton and other agricultural products.

In the first, the concept of creating a multilevel automated management system for the agro-industrial complex based on the ideas of algorithmization, developed by Academician of the Republic of Uzbekistan V.K. Kabulov, was put forward in the work[1]. It is of great scientific importance even now.

This is primarily due to the fact that, according to this concept, agriculture and other branches of the agro-industrial complex are considered as interconnected and interacting territorially sectorial dynamic systems that ensure the efficiency of using land, water and other resources in the production, processing and marketing of agricultural goods and raw materials. In addition, the work provides models of territorial - sectorial and within the economic location of industries, describes methods of water resources management. Subsequently, they formed the basis for the simulation system developed within the framework of the concept within economic planning and resource use [2]. Macroeconomic models for the analysis and forecasting of the rates and proportions of agricultural development were developed by T.Sh. Shodiev [3]. In particular, the principles and methods of macroeconomic analysis and forecasting based on models of the econometric type were first substantiated, which were later developed to study the prospects for the development of agriculture in the republic in the agro-industrial complex [4]. The scientific significance of these works for the practice of modeling the agroindustrial complex remains in the market conditions, since the model building scheme is based on the statistical direction of the structure of production and reproduction processes. 
Another group of works on macroeconomic modeling is devoted to the problems of regional development and placement of the agro-industrial complex and the national economic cotton complex. They provide the theoretical foundations for the formation of the regional agro-industrial complex and its specialized complexes. In the work of S.S.Gulyamov, the optimization approach to the corresponding management model of the territorial-sectorial structure of the agroindustrial complex of cotton specialization is substantiated. K.S. Safayeva's work proposes a model of multilevel optimization of the production structure of the national economic cotton complex and methods of coordinating planning decisions. The main advantage of the approaches to modeling outlined in is that in them the options for technological methods of production and, accordingly, the use of resources [5]. This approach ensures the choice of effective development options for a given volume of production resources.

\section{MAIN PART}

Analysis of the results of these studies shows that their main idea is the attempt of the authors of mathematical to formalize the conditions for the functioning of the economy in their linkage with the parameters of technological methods of production and processing of agricultural products. This approach as a whole makes it possible to model agro-economic processes based on the laws in the agricultural system and its constituent elements and subsystems.

However, it should be noted that individual models and algorithms for their implementation are complex in mathematical description and cumbersome to understand. In addition, they are linked to the aggregated information generated in the centralized control system. Therefore, such classes of models, especially of the optimization type, must be worked out from the point of view of their information base and methods of their implementation on a computer.

However, there are some gaps in the development of agro-economic process models. First of all, this relates to the creation of models of bio-ecosystems for the management of soil fertility and plant development under irrigation conditions. Such studies are the basis for the automation of land appraisal and land use control. Another problem is the creation of scientific foundations, methods and models for controlling the feeding system and programming the productivity of animals. The experience of foreign countries shows the effectiveness of such research, which allows the creation of computer systems for the management of animal feeding to obtain highly programmed products. This complex and multifaceted problem, the solution of which depends not only on cyberneticists, but also on scientists of livestock breeders in the conditions of the state sovereignty of Uzbekistan, it is important to solve the problem of a comprehensive assessment of the prospects for the development of agricultural production, taking into account its influence on the formation of the consumption model of agricultural mudflow development.

In such conditions, it is important to solve the problem of creating a mechanism for regulating the agrarian economy at the macro level. This mechanism should provide the state management bodies of the agroindustrial complex with information on the scale of production, the expected size of consumed resources, products, as well as the levels of income received by the state budget. This requires the creation on the basis of computer networks of distributed information structures in the state administration bodies of the agro-industrial complex, with a double function. The first is the provision of information services to farmers, tenants, cooperatives and others, and the second is 
the accumulation of statistics and production information from the microenvironment to predict the future development of agriculture, demand, price levels, etc. at the macro level.

All this will make it possible to develop state measures to support agriculture, regulate the distribution of income, resources and national wealth to ensure sustainable development of the agrarian economy of the Republic.

Regardless of what forms of relationship are used on farms, the main source of income is proceeds from the sale of agricultural products. The amount of the planned revenue is calculated as follows:

At present, in a market economy, the development of agriculture is associated with the effective restructuring of all branches of the agro-industrial complex. Difficulties in solving this problem are associated, on the one hand, with the lack of methods and incomplete knowledge on a comprehensive assessment of the activities of agricultural enterprises in a market environment and, on the other hand, the lack of experienced specialists. The solution to this problem necessitates the creation of machine-oriented methods. When creating machine-oriented methods, the main points are the selection and development of a base of analytical and heuristic knowledge, which makes it possible to comprehensively assess the activities of agricultural enterprises. At the same time, one of the important calculation components is the method for assessing the activity of the indicator in terms of the efficiency of land use.

Regardless of what forms of relations are adopted in farms, the main source of income is the proceeds from the sale of agricultural products or services rendered. The amount of planned revenue is calculated as follows:

$$
W=\sum_{j=1}^{J} \sum_{i=1}^{I} U_{i j} Q_{i j}
$$

where $\mathrm{W}$ is the amount of proceeds from the sale of agricultural products; $\mathrm{U}_{\mathrm{ij}}$ - unit price of the $\mathrm{i}$-th product of the $\mathrm{j}$-th range; $\mathrm{Q}_{\mathrm{ij}}$ is the natural volume of products of the i-th type of the j-th assortment. After reimbursement of material costs for the production of agricultural products, gross income is generated. In this case, material costs are formed in this way:

$$
M=\sum_{i=1}^{I} m_{i}^{1} P_{i}+\sum_{i=1}^{I} \sum_{j=1}^{J} m_{i j}^{2} Q_{i j}
$$

Here $M$ is the amount of material costs (sum), $m_{i}^{1}$ - coefficient of material capacity of the i-th product per unit of sown area; $P_{i}$ - sown area (livestock) for the production of the i-th product; $m_{i j}^{2}$ - coefficient of material capacity of products of the $i$-th type of the $j$-th assortment per unit of production. The gross volume is determined as follows:

$$
V=W-W^{+}-M-W^{-}
$$

Where $V, W^{+}, W$ - respectively the volumes of gross and unplanned income, as well as unplanned expenses and losses. In the context of the introduction of a new economic mechanism, an important place is given to profit - an indicator of the final result of the activities of labor collectives. Profit is the excess of proceeds from the sale of products over the costs of its production. To calculate the cost of marketable products, it is necessary to take into account all costs for it, both for production and sales, for example, the costs of production of crop products are as follows: wages, cost of seeds, planting material, fuel and lubricants, fertilizers, freight transportation, depreciation, expenses for the current repair of fixed assets, other fixed, general production and general expenses. The costs of its implementation include the costs of containers, packaging, loading, delivery of products to procurement and other organizations.

The mathematical description of profit is 


$$
\Pi=W-C
$$

Where $\Pi$ is the profit from the sale of manufactured products; $C$ - total cost of goods sold. To calculate the total cost of production, you can use the methods and algorithms given in the works $[2,3]$. It should be noted that land resources are limited in agriculture. Therefore, the issues of increasing the level of efficiency of land use occupy a particularly important place. To do this, it is necessary to enter such an indicator that will allow the lessor to assess the level of use by tenants of each hectare of land. In the future, this indicator will be called the land use coefficient, determined by the formula

$$
K_{u c n}=\frac{\Pi_{T}}{\Pi_{B}}
$$

Here $\Pi_{T}$ is the amount of profit received from one hectare in the current year; $\Pi_{\mathrm{b}}$ - profit per hectare last year.

Thus, in the context of the introduction of a new economic mechanism in agriculture, an especially important place is occupied by such an indicator as the coefficient of land use.

\section{CONCLUSIONS}

Econometric models of farm development must first examine the influence of sectorial factors and ensure that the necessary conclusions can be drawn from them. This imposes certain requirements on the models under construction.

The above models are simple forms of mathematical description of complex processes, but they also serve the most basic tasks.

The main goal of the study is to prevent the construction of complex models in econometric modeling of complex multifactorial economic activity.

\section{REFERENCES}

1. Decree of the President of the Republic of Uzbekistan No. UP-4947 dated February 7, 2017 "On the strategy of actions for the further development of the Republic of Uzbekistan" // Collected Legislation of the Republic of Uzbekistan, 2017, No. 6, Article 70.

2. Кабулов В.К., Абдуразаков В.А., Зияходжаев М.3. Применение математических методов в хлопководстве. - Ташкент: «Фан», 1974.139c.

3. Шадиев Т.Ш. Экономические модели развития сельского хозяйстве. Ташкент: «Фан», 1986.-168с.

4. Бекинов Б., Тургунов С., Махмудов Б. Многоуровневая модель и имитационная система внутрихозяйственного планирования в сельскохозяйственных предприятиях//Экономико-

математические методы. - М.: «Наука», 1990.-Т.26.-Вып.6.

5. Сафаева К. Математические модели и методы оптимизации народнохозяйственного хлопкового комплекса. Ташкент: «Фан», 1980.-98с

6. Убайдуллаева Р.А. Новый этап в социально-экономическом и инновационном развитии Республики Узбекистан // Общественное мнение. Права человека, 2018. - № 1. - С. 19-35.

7. Cornwell B. Social Sequence Analysis: Methods and Applications - Cambridge: Cambridge University, Press, 2015. - 337 p.

8. Clarke A.E., Friese C. Situational Analysis in Practice: Mapping Research with Grounded Theory - L.: Routledge, 2015. $347 \mathrm{p}$.

9. Коротаевский, Анатолий Геннадьевич. Эконометрические методы: Учебное пособие/ 6.Коротаевский, Анатолий 
Геннадьевич, Анатольевна. - Саранск: Изд-во СВМО, 2004. - 124 C.

10. Луговская, Людмила Владимировна. Эконометрика в вопросах и ответах: учебное пособие / Луговская, Людмила Владимировна. - М.: Проспект, 2005. 208 c.

11. Kh.S. Mukhitdinov, F.D. Juraev. Methods of Macroeconomic Modeling. International Journal of Trend in Scientific Research and Development (IJTSRD), eISSN: 2456 - 6470, 29-32 pag, https://www.ijtsrd.com/papers/ijtsrd3849 8.pdf 